\title{
Retraction Notice: S. Nikolaeva, Bologna Process in Ukraine: The Decade Anniversary, International Letters of Social and Humanistic Sciences, Vol. 66, pp. 103-112, 2016 \\ Editorial office of International Letters of Social and Humanistic Sciences

\author{
Seestrasse 24c, $\mathrm{CH}-8806$ Bach, Switzerland \\ ilshs@scipress.com
}

This article has been retracted at the request of the Editor-in-Chief.

Recently, we have become aware of a case of duplicate publication. The article [1] had been published previously in the journal General and Professional Education [2].

The paper was submitted to the General and Professional Education (GPE) six months prior to the date of submission to the International Letters of Social and Humanistic Sciences (ILSHS). The author explained the duplicate submission to the ILSHS by the reason that the Editorial office of the GPE had not kept the author informed about any updates of the paper as well as about the fact of its publication. Manuscripts may not be duplicated. Such publication is considered to be a publication malpractice. Therefore, the article was a subject to retraction for the purpose of literature correction as per to COPE's Retraction Guidelines [3].

The author of [1] has been informed about the decision to retract the article [1] and agreed to the retraction. Thereafter the paper has been declared retracted and marked accordingly.

\section{References}

[1] S. Nikolaeva, Bologna Process in Ukraine: The Decade Anniversary, International Letters of Social and Humanistic Sciences. 66 (2016) 103-112. DOI: 10.18052/www.scipress.com/ILSHS.66.103.

[2] S. Nikolaeva, The Bologna process in Ukraine: the decade anniversary, General and Professional Education. 2015(4) (2015) 66-74.

[3] Committee on Publication Ethics, Retraction Guidelines. Available: https://publicationethics.org/files/retraction\%20guidelines.pdf. 